\title{
Sir James Paget
}

\section{Siddharth Pramod Dubhashi • Rajat Dinesh Sindwani}

Published online: 18 August 2013

(C) Association of Surgeons of India 2013

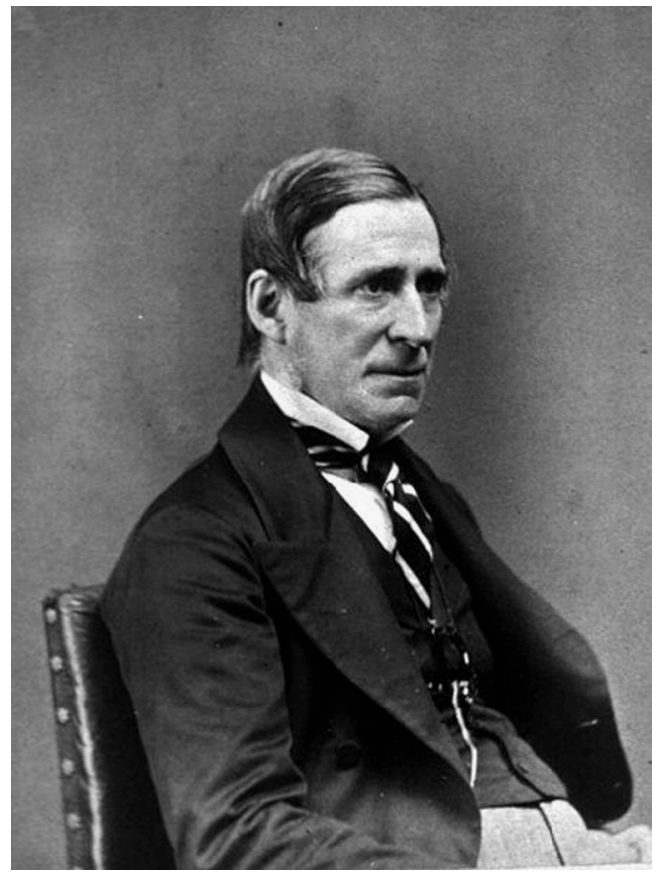

Sir James Paget [13]

James Paget was born in Great Yarmouth, Norfolk, UK, on 11 January 1814 [1]. Paget began an apprenticeship as a surgeon apothecary in 1830 at the age of 16 years. He and his brother Charles studied the flora and fauna of Great Yarmouth and published a book in 1834 called The Natural History of Yarmouth and Its Neighbourhood [2].

S. P. Dubhashi $(\bowtie) \cdot$ R. D. Sindwani

Padmashree Dr. D.Y. Patil Medical College, Hospital and Research Centre, Dr. D.Y Patil Vidyapeeth, Pimpri, Pune, Maharashtra, India e-mail: spdubhashi@gmail.com

He later began a 2-year period of study at St. Bartholomew's Hospital in London on 3 October 1834. He spent much time in the dissecting room during his training, like many others who aspired to become a surgeon [3]. Paget's greatest achievement as a medical student was in 1835 , when he described Trichinella spiralis commenting that "All the men in the dissecting rooms, teachers included 'saw' the little white specks in the muscles, but I believe that I alone 'looked at' them and 'observed them"' [1, 2]. In 1836, Paget was appointed as curator of the pathology museum at St. Bartholomew's Hospital, where he published a 487-page catalogue of the pathological specimens [2]. In 1838, he was infected with typhus while conducting a post-mortem and was critically ill for more than 6 weeks.

The Royal College of Surgeons elected Paget as a fellow in 1846. Subsequently in 1847 , he was appointed as the Aris and Gale Professor of the Royal College where he delivered lectures on nutrition (1847), the life of the blood (1848), the process of repair and reproduction after injuries (1849), inflammation (1850), tumours (1851) and malignant tumours (1852). These lectures formed the basis of his book Lectures on Surgical Pathology [4]. In 1849, he published a descriptive catalogue of the specimens in the Hunterian Museum. He became a member of the Societe de Biologie and the Societe Chirurgie in Paris in 1856. He was appointed Surgeon Extraordinary to her Majesty Queen Victoria in 1858 and Surgeon-in-Ordinary to His Royal Highness, the Prince of Wales in 1863 . He was awarded the honorary degree of Doctor of Laws by the University of Oxford and the honorary Doctorate of Medicine by the University of Bonn in 1866. He was granted the title of Sergeant Surgeon Extraordinary in 1867 [5]. In 1871, the queen conferred on him a baronetcy. The motto on his coat of arms read 'Labouripse voluptas' (work itself is pleasure). 
Paget's contributions to surgery are as follows [2, 6-12]:

- Paget's description of neurofibromatosis

- Paget's description of hereditary multiple exostosis

- Paget's description of painful subcutaneous tumours

- Paget's description on viruses in relation to cancer susceptibility and cancer resistance

- Paget's disease of the nipple

- Paget's disease of the bone

- Paget's description of osteochondritis dissecans (OsgoodSchlatter disease)

- Paget's skin neoplasm usually involving the anogenital area

- Axillary vein thrombosis

- Paget's recurrent fibroid (desmoid tumour)

- Paget's residual abscesses

- Paget's disease of jaw

- Paget's disease of penis

- Paget's test to demonstrate fluctuation in case of small swellings

In 1883, he was elected Vice Chancellor of the University of London. Paget had the gift of eloquence and was a delightful speaker of his time. His ideal was the unity of science and practice in professional life. Sir James Paget died on 30 December 1899.

\section{References}

1. Roberts S (1989) Sir James Paget. The rise of clinical surgery. In: L'Etang H (ed) Eponymist in medicine. Royal Society of Medicine Services Limited, London

2. Buchanan WW (2003) Sir James Paget. Rheumatology 42:1107-1108

3. Zantinga AR, Coppes MJ (1992) Max Wilms (1867-1918): the man behind the eponym. Med Pediatr Oncol 20:515-518

4. Turk JL (1995) Sir James Paget and his contributions to pathology. Int J Exp Path 76:449-456

5. Reed K, Grage TB (1982) The Paget tradition revisited. Am J Surg $144: 498-503$

6. Krush, Anne J (1973). Sir James Paget contribution to cancer genetics. Transactions of the Nebraska Academy of Sciences and Affiliated Societies. Paper 382.

7. Paget J (1865) Lectures on surgical pathology. Lindsay and Blakiston, Philadelphia

8. Paget J (1851). Lectures on tumours. London, Wilson and Ogilvy, pp 328-391, 460-462 and 487-542.

9. Paget J (1887) The Morton lecture on cancer and cancerous diseases. Longmans, Green and Company, London

10. Buchanan W (1996) The contribution of Sir James Paget to the study of rheumatic disease. Clin Rheumatology 15:461-472

11. Das S (2012). Swellings of jaw Ch. 23 and The penis Ch. 52. In: A concise textbook of surgery, 7th Ed. Kolkata: pp 428 and 1345.

12. Das S (2011). Examination of a swelling Ch 3. In: A manual on clinical surgery 9 th ed. Kolkata, pp 30.

13. The medical profession in all countries containing photographic portraits from life 1 (15). London: J \& A. Churchill, 1873. http://ihm.nlm. nih.gov/images/A19115. Accessed 9 May 2013. 